\title{
How Collaboration Between Industrial Designers and Other Members Related to Product Development Affect Innovation and Efficiency
}

\author{
Senju HANAHARA ${ }^{\text {a) }}$
}

\begin{abstract}
Interdepartmental collaboration is considered to be critical to innovation and efficiency. This paper differentiated industrial design (ID) and engineering design (ED), which differ in their nature and are handled by different departments, and reviews in the literature on the impact that interdepartmental collaboration among industrial designers and other areas involved in product development has on innovation and efficiency. We found that: (1) regarding innovation, interdepartmental collaboration has a positive effect on design innovation, and CE type interdepartmental collaboration has a positive effect on technology innovation. (2) Regarding efficiency, we found that the effect on the efficiency of the product development process was not consistent, and production efficiency was not looked into in prior research.
\end{abstract}

\footnotetext{
a) Graduate School of Economics, The University of Tokyo, Hongo 7-3-1, Bunkyo-ku, Tokyo, 113-8654, Japan, flowerfield8787@gmail.com

A version of this paper was presented at the ABAS Conference 2021 Winter (Hanahara, 2021).

(C) 2021 Senju Hanahara. This is an Open Access article distributed under the terms of the Creative Commons Attribution License CC BY 4.0 (Attribution 4.0 International) license. The CC BY 4.0 license permits unrestricted reuse, distribution, and reproduction in any medium, provided the original work is properly cited.
} 
Keywords: design management, innovation, efficiency, collaboration, product development

\section{Introduction}

Looking at changes in consumer preferences, we can see that buying decisions are becoming more susceptible to emotional needs and desires (Czarnitzki \& Thorwarth, 2012) and that putting products with a design focus on the market is a factor in competitive advantage (Nobeoka, 2006). This study therefore addresses the design stage part of product development.

Research on design management proves that innovation and efficiency are key to performance (Dickson, Schneier, Lawrence, \& Hytry, 1995), and design research and product development research proves that interdepartmental collaboration is key to innovation and efficiency. However, in the context of management, the term "design" can mean many different things, and these differences have complicated ongoing research on design (Verganti, 2008). Most articles discuss the topic without differentiating between design as a "sketch made during the design stage" and design as "a blueprint made during the product engineering stage." In product development, the person who draws the sketch is usually not the same person who draws the blueprint, and the departments in charge of these tasks are different as well. The art of designing a sketch is considered to require individual skill and does not take well to organizational efforts (Hemonnet-Goujot, Manceau, \& Abecassis-Moedas, 2019; Kanki \& Osanai, 2018). Thus, both being regarded as design in the broad sense is problematic (Hertenstein, Platt, \& Veryzer, 2005).

This paper therefore classifies design in the broad sense as (A) industrial design (ID), which determines the form of an industrial 
product and (B) engineering design (ED), which designs product functions (Kanki \& Osanai, 2018). Upon differentiating the natures of ID and ED, we classify the types of interdepartmental collaboration, and based on these classifications, we investigate how innovation and efficiency were affected in prior research, identify the research gaps in current design research, and indicate directions for future research.

\section{Type of Collaborations}

ID is part of the product development process. It is also related to product aesthetics, user friendliness, manufacturability, the efficient use of materials, and product performance (Gemser \& Leenders, 2001). Instead of calling it ID, some studies call decisions about a product's color, materials, form, and size parameters "product form design" (PFD) (Rindova \& Petkova, 2007), and others call the aesthetic and symbolic choices about the combination of a product's traits "style" (Cappetta, Cillo, \& Ponti, 2006), but this paper regards PFD and style as being the same as ID.

As shown in Figure 1, the product development process takes place in a flow from (1) the product concept to (2) product planning to (3) product engineering to (4) process engineering to (5) manufacturing (Clark \& Fujimoto, 1991). The areas responsible for the various steps differ from company to company, but they are usually as follows (Takeda, 2000):

(1) Product concept stage: Those in charge of creating the product concept in the marketing department or elsewhere formulate a product concept based on market data, technological information and other such criteria.

(2) Product planning stage: Designers (IDs) and others execute the 
Figure 1. Product development process

Source: Created by the author from Takeda (2000)

styling, which incorporates the specific elements of the product concept.

(3) Product engineering stage: Based on the product plan, EDs create ED, build prototypes and run it through repeated tests.

(4) Process engineering stage: The production technology team plans the production process.

(5) Manufacturing stage: Manufacturing begins.

Many methods of interdepartmental collaboration in the product development process have been suggested. Although most prior research on interdepartmental collaboration has not differentiated between ID and ED,

(i) While ID research has investigated collaboration between industrial designers and other departments,

(ii) most product development research has not emphasized ID, but has looked at post-ED interdepartmental collaboration and suggested various collaborative models, such as the sequential model, the overlapping model, concurrent engineering (CE), and front-loading model (such as Itohisa, 2012; Takeda, 2000; and Thomke \& Fujimoto, 2000).

Here, the collaborative models in (ii) are roughly divided into: (a) the sequential model, in which the departments act in sequence, and (b) the overlapping model, $\mathrm{CE}$, and front-loading, which proceed with 
a number of activities simultaneously, by which those in charge of product development collaborate in the product development process from the beginning, and in which problems are solved preemptively. Here in (a) the sequential model, ID, ED, and manufacturing are split up and performed sequentially, and communication flows in one direction, with the output of the problem solving done by the upstream departments flowing as input to the downstream departments (Takeda, 2000)

In contrast, in overlapping model (b), the downstream process starts before the upstream processes are finished (Takeda, 2000). CE is a similar concept (Itohisa, 2009). Here, marketing, product engineering, process engineering, manufacturing plans, and supply activities overlap, and the product development people are involved from the beginning and are part of the interdepartmental team (Koufteros, Vonderembse, \& Doll, 2001). In the overlapping model, front-loading (Thomke $\&$ Fujimoto, 2000) is possible. Front-loading is defined as "a strategy that seeks to improve development performance by shifting the identification and solving of ED problems to earlier phases of a product development process," and it is achieved through knowledge transfer among projects and quick problem solving.

In the following, we focus on and identify two types of interdepartmental collaborations with regard to innovation and efficiency, which are considered key to performance: (i) collaboration between ID and other departments and (ii) post-ED collaboration.

\section{Effects on Innovation}

As it is said that having a dominant ID gives a competitive advantage to a firm (Akiike, 2017), the importance of design innovation is being acknowledged. This paper therefore discusses innovation in terms of (1) design innovation and (2) technology 
Coordination

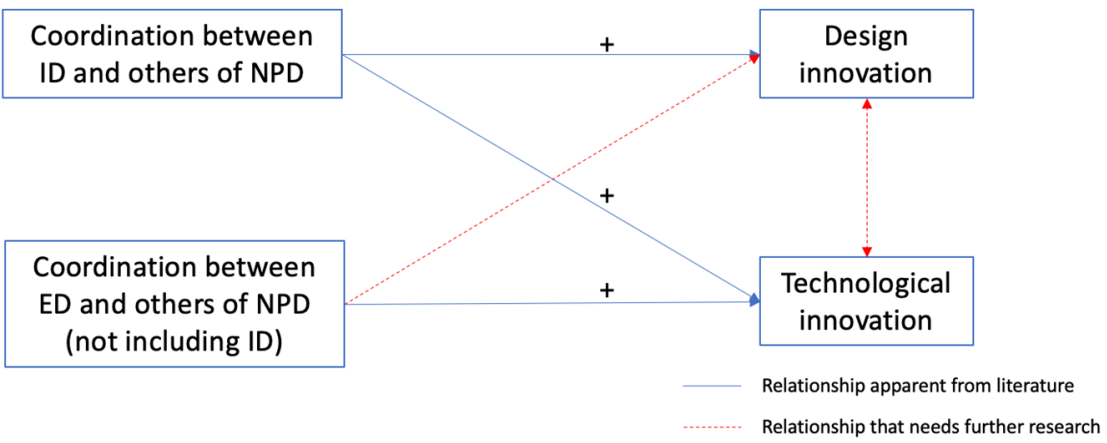

Figure 2. Relationship between coordination and innovation

Source: Created by the author from Hara, Hirasaka, and Tatsumoto (2019), Kanno and Shibata (2013), Koufteros, Vonderembse, and Doll (2001), and Yoshioka (2018)

innovation. Design innovation involves appearance and user friendliness, while technology innovation gives a product new functionality. Both contribute to product competitiveness (Akiike, 2014). According to prior research, (i) interdepartmental collaboration between industrial designers and other departments engenders design innovation, while collaboration between industrial designers and technology areas engenders technology innovation, and (ii) $\mathrm{CE}$ has a positive effect on technology innovation in post-ED interdepartmental collaboration (Figure 2).

\section{(1) Design innovation}

Design innovation means creating an additional external layer to technology innovation (Fjaellegaard, Beukel, \& Alkærsig, 2019; Rindova \& Petkova, 2007) or creating a superior product by integrating technology innovation and design innovation (Fjaellegaard et al., 2019). It refers to giving new meaning to new products that have been created by changing a product's aesthetic 
qualities through reallocating the social meaning of an existing product (Cappetta et al., 2006).

Regarding design innovation, Kanno and Shibata (2013) sent a questionnaire to companies that had been awarded the Good Design Prize to investigate the impact of three factors in interdepartmental coordination activities: compromise (the extent to which ID compromises with other departments), integration (the closeness between ID and other departments), and conciliation (the degree to which other departments influence and meddle in ID). These were based on the four design outputs of consistency, customer orientation, autonomy, and innovation. They found that the three factors had a positive effect on design output. For innovation, all three factors had a positive effect, and the effect of integration was especially strong. This was thought to happen because integration leads to many exchanges of knowledge and to the creation of innovative designs.

Also, Hara, Hirasaka, and Tatsumoto (2019), in a network analysis using data on design patents, found that when a product group was aiming for a coherent design, the designer, engineer, and manager maintained a very close network to facilitate the transmission of tacit knowledge, which enabled design innovativeness and brand coherence. Thus, this showed that collaboration between designers and other departments can lead to the simultaneous achievement of both design innovation and brand coherence.

\section{(2) Technology innovation}

Regarding technology innovation, Yoshioka (2018) investigates cases where designers were involved in the invention of patented technology out of 90 products that received international design awards. The result was that when designers were involved in technology development, (a) new component technologies were developed, which led to new product concepts, (b) setting of technical 
issues and sharing of technology developments within the team were encouraged, raising the engineers' development efficiency, and (c) bridging other departments' technologies to create new technologies led to the creation of high-quality technology and improved product quality as well.

In addition, Koufteros et al. (2001) administered a questionnaire which showed that post-ED $\mathrm{CE}$ has a direct positive effect on technology innovation (the number of new products, the number of new functions, etc.), the reason being that the transmission of information about technology that conforms with needs can be obtained through $\mathrm{CE}$.

\section{(3) Relationship between design innovation and technology innovation}

Although design innovation is considered to be endogenous to technology innovation, the correlation between design innovation and technology innovation has not been adequately investigated, so it is not clear how interdepartmental collaboration affects this correlation. Cappetta et al. (2006) mentioned as a possibility that innovations in materials and production systems could increase the tools for design innovation, and Fjaellegaard et al. (2019) suggested as the limitation of their research that technology is distributed through a firm's many departments. Thus if designers are involved in the product development process, design innovation could be generated.

Akiike and Yoshioka-Kobayashi (2017) use a quantitative study on digital cameras to argue that technology innovation is an ID constraint and causes ID to change. In addition, Akiike (2017) uses a quantitative study on Japan's unique mobile phones (Galapagos keitai) to argue that the dominant ID will change to a form that responds to technology innovations that meet changes in needs. Thus, technology innovation is thought to influence design innovation. On the other hand, Yoshioka (2018) says that technology 
innovation is stimulated when industrial designers are involved in technology development, so design innovation and technology innovation probably influence each other.

Thus, prior research indicates that (1) collaboration between industrial designers and other departments has a positive effect on design innovation and technology innovation, (2) the use of CE and other types of collaborative models is desirable in technology innovation, and (3) design innovation and technology innovation influence each other.

\section{Effects on Efficiency}

(1) How collaboration between ID and others related to product development affect productivity

Hertenstein et al. (2005) defines the role of the ID as coordinating with other departments and working to achieve prompt agreement within the product development team regarding product design that has good production efficiency, but this investigation did not address how to improve production efficiency.

(2) How collaboration between IDer and others related to product development affect efficiency of the product development process

The research findings are divided into whether the process becomes more efficient or more inefficient.

The product development process is also called the design process. ${ }^{1}$ Based on prior research, Chiva-Gomez (2004) identifies four design management activities that improve the efficiency of the product

1 This is defined as the strategic activities that are used in creating a product design, from the inception of an idea to commercialization (Luchs \& Swan, 2011). 
development process: (1) stronger relations between members within the company and from outside; (2) the development of interdepartmental relations within the product development process, (3) maximization of information flows, and (4) the encouragement of heterogeneous participation in design decision making. Also, based on a quantitative study, Zhang, $\mathrm{Hu}$, and Kotabe (2011) found that collaboration between industrial designers and marketing can result in a more efficient product development process.

Meanwhile, Perks, Cooper, and Jones (2005) argue that collaboration between industrial designers and other departments makes the product development process more inefficient instead. Using a qualitative analysis, they classify the role of the industrial designer into three types: (1) the functionally specialized designer, (2) the designer as part of a multifunctional team, and (3) the designer as a new product development (NPD) leader. They showed that the designer who belongs to a multifunctional team collaborates with other functions through the product development process and may be involved in building prototypes and manufacturing. Although this type was achieving radical product development as a result of creativity provided by external designers, it took time for external designers to be integrated into the team, so overall product development efficiency was low.

As for whether the impact of collaboration between industrial designers and other departments on the efficiency of the product development process is positive or negative, this will have to be addressed in a more detailed study in the future. Another future research topic is the effect on production efficiency.

(3) Collaboration between ED and later stages of product development improves efficiency of the product development process and productivity when using overlapping model and front-loading

Thomke and Fujimoto (2000) showed that the product development 
Coordination

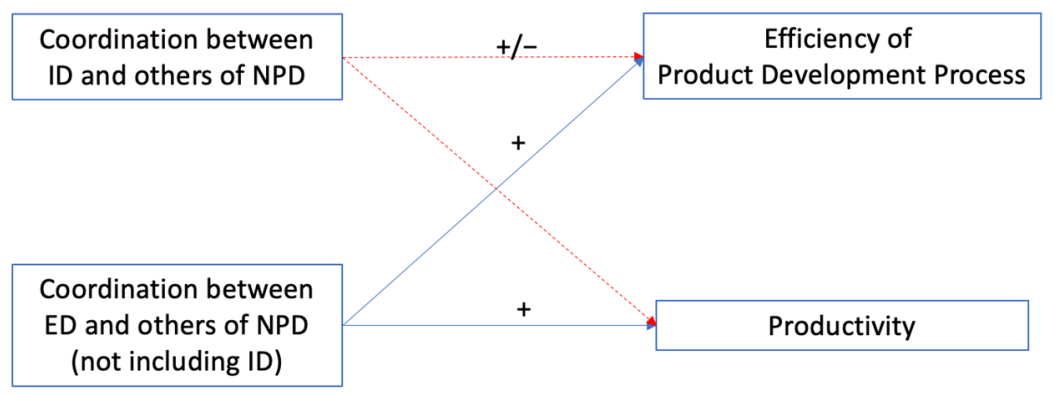

Figure 3. Relationship between coordination and efficiency

Source: Created by the author from Chiva-Gomez (2004), Clark and Fujimoto (1991), Itohisa (2012), Perks, Cooper, and Jones (2005), Thomke and Fujimoto (2000), and Zhang, Hu, and Kotabe (2011)

process becomes more efficient when front-loading is used to identify and resolve design problems in the early stages of the product development process. Also, Clark and Fujimoto (1991) assert that front-loading of the problem discovery and resolution cycle in consideration of problems that occur in the downstream area of development makes it possible to resolve manufacturability problems. Using case studies, Itohisa (2012) argues that when the overlapping model of problem solving cannot ensure the robustness of information in upstream processes, downstream processes may become inefficient due to repeated revisions of processes, but if frontloading takes place, the information about upstream processes becomes robust, making the overall performance improve. Furthermore, Itohisa points out, manufacturability problems are resolved through overlapping model problem solving.

The foregoing is summed up in Figure 3. 


\section{Conclusion}

This paper distinguished ID and ED, and classified interdepartmental collaboration into (i) collaboration between industrial designers and other departments and (ii) post-ED interdepartmental collaboration, then identified their impact on performance as represented by innovation and efficiency.

Regarding innovation, the following two points were made: (1) interdepartmental collaboration between industrial designers and other departments involved in product development has a positive effect on design innovation and (2) the CE type of interdepartmental collaboration between industrial designers and other departments involved in product development has a positive effect on technology innovation. However, the following two points are topics for future research: (1) How does technology innovation influence design innovation and how does design innovation influence technology innovation? (2) How does interdepartmental collaboration affect (1)?

Regarding efficiency, we know that the product development process and production efficiency will improve depending on the state

Table 1. Relationship between coordination and innovation/efficiency

\begin{tabular}{|c|c|c|c|c|c|}
\hline Performance & \multicolumn{3}{|c|}{ Innovation } & \multicolumn{2}{|c|}{ Efficiency } \\
\hline $\begin{array}{l}\text { Coordination between ID and others } \\
\text { of NPD }\end{array}$ & $\begin{array}{l}\text { Hara et al.(2019) } \\
\text { Kanno \& Shibata(2013) }\end{array}$ & Yoshioka (2018) & & $\begin{array}{l}\text { Chiva-Gomez(2004) } \\
\text { Zhang et al. (2011) }\end{array}$ & \\
\hline & & & & Perks et al.(2005) & \\
\hline $\begin{array}{l}\text { Coordination between ED and others } \\
\text { of NPD (not including ID) }\end{array}$ & & Koufteros et al.(2001) & & $\begin{array}{l}\text { Itohisa (2012) } \\
\text { Thomke \& Fujimoto } \\
(2000)\end{array}$ & $\begin{array}{l}\text { Clark \& Fujimoto } \\
\text { (1991) } \\
\text { Itohisa (2012) }\end{array}$ \\
\hline
\end{tabular}

Note: Blue highlight: negative effect

Source: Created by the author from Chiva-Gomez (2004), Clark and Fujimoto (1991), Hara, Hirasaka, and Tatsumoto (2019), Itohisa (2012), Kanno and Shibata (2013), Koufteros, Vonderembse, and Doll (2001), Perks, Cooper, and Jones (2005), Thomke and Fujimoto (2000), Yoshioka (2018), and Zhang, Hu, and Kotabe (2011 
of post-ED collaboration, but in the case of interdepartmental collaboration between industrial designers and other departments, (1) the impact on the efficiency of the product development process is not consistent, so additional research needs to be pursued on the topic. ${ }^{2}$ (2) Prior research did not look into production efficiency, so research needs to be performed on whether IDs, who are of a different nature than EDs, can, for instance, improve production efficiency by overlapping.

\section{Acknowledgments}

This work was supported by JSPS Grant-in-Aid for Publication of Scientific Research Results, Grant Number JP16HP2004.

\section{References}

Akiike, A. (2014). Can firms simultaneously pursue technology innovation and design innovation? Annals of Business Administrative Science, 13, 169-181. doi: 10.7880/abas.13.169

Akiike, A. (2017). Establishing Galapagos ke-tai's dominant industrial design. Annals of Business Administrative Science, 16, 287-300. doi: 10.7880/abas.0170916a

Akiike, A., \& Yoshioka-Kobayashi, T. (2017). The power of existing design for establishing the dominant "industrial" design. Annals of Business Administrative Science, 16, 189-202. doi: 10.7880/abas.0170410a

Cappetta, R., Cillo, P., \& Ponti, A. (2006). Convergent designs in fine fashion: An evolutionary model for stylistic innovation. Research Policy, 35, 1273-1290. doi: 10.1016/j.respol.2006.02.009

Chiva-Gomez, R. (2004). Repercussions of complex adaptive systems on product design management. Technovation, 24(9), 707-711. doi: 10.1016/S0166-4972(02)00155-4

2 Perks et al. (2005) points out that positioning the industrial designers externally results in inefficiency. 
Clark, K. B., \& Fujimoto, T. (1991). Product development performance. Boston, MA: Harvard Business School Press.

Czarnitzki, D., \& Thorwarth, S. (2012). The contribution of in-house and external design activities to product market performance. Journal of Product Innovation Management, 29(5), 878-895. doi: 10.1111/j.15405885.2012.00935.x

Dickson, P., Schneier, W., Lawrence, P., \& Hytry, R. (1995). Managing design in small high-growth companies. Journal of Product Innovation Management, 12(5), 406-414. doi: 10.1016/0737-6782(95)00056-9

Fjællegaard, C. B., Beukel, K., \& Alkærsig, L. (2019). Designers as the determinants of design innovations. Creativity and Innovation Management, 28(2), 144-156. doi: 10.1111/caim.12302

Gemser, G., \& Leenders, M. A. (2001). How integrating industrial design in the product development process impacts on company performance. Journal of Product Innovation Management, 18(1), 2838. doi: 10.1016/S0737-6-782(00)00069-2

Hanahara, S. (2021, January). How collaboration between industrial designers and other members related to product development affect innovation and efficiency. Paper presented at ABAS Conference 2021 Winter, University of Tokyo, Japan.

Hara, H., Hirasaka, T., \& Tatsumoto, H. (2019). Design jushi no seihinkaihatsu niokeru design management: Consumer electronics kigyo no hikaku bunseki [Managing design in design-oriented product development: A comparative study of consumer electronics companies]. Soshiki Kagaku [Organizational Science], 52(3), 4-19 (in Japanese). doi: 10.11207/soshikikagaku.52.3_4

Hemonnet-Goujot, A., Manceau, D., \& Abecassis-Moedas, C. (2019). Drivers and pathways of NPD success in the marketingexternal design relationship. Journal of Product Innovation Management, 36(2), 196-223. doi: 10.1111/jpim.12472

Hertenstein, J. H., Platt, M. B., \& Veryzer, R. W. (2005). The impact of industrial design effectiveness on corporate financial performance. Journal of Product Innovation Management, 22(1), 321. doi: $10.1111 / \mathrm{j} .0737-6782.2005 .00100 . \mathrm{x}$

Itohisa, M. (2009). Seihinkaihatsu process-ron niokeru model-based 
framework no kanousei [The possibility of model-based framework in product development process research]. Akamon Manejiment Rebyu [Akamon Management Review], 8(6), 337-350 (in Japanese). doi: 10.14955/amr.080602

Itohisa, M. (2012). Overlap-gata seihinkaihatsu niokeru front-loading no koka [The effect of front-loading on overlapping product development model]. Akamon Manejiment Rebyu [Akamon Management Review], 11(4), 237-254 (in Japanese). doi: 10.14955/amr.110401

Kanki, M., \& Osanai, A. (2018). Seihinkaihatsu niokeru kougyo-design to kino-sekkei no togo: A sha no keitaidenwatanmatsu no gaiso-design kaihatsujirei [Integration of industrial design and enginerring design: A case of cosmetic design development in a cell phone manufacturer A]. Waseda Kokusai Keiei Kenkyu [Waseda bulletin of international management], 49, 69-82 (in Japanese). Retrieved from https://core.ac.uk/download/pdf/154931311.pdf

Kanno, Y., \& Shibata, S. (2013). Seihin design ni kakawaru soshiki yoin to bumonkan-chosei [Organizational factor and coordination in relation to product design]. Nihon Keieigaku Kaishi [Japan Society of Business Administration], 32, 55-68 (in Japanese). doi: 10.24472/keieijournal.32.0_55

Koufteros, X., Vonderembse, M., \& Doll, W. (2001). Concurrent engineering and its consequences. Journal of Operations Management, 19(1), 97-115. doi: 10.1016/S0272-6963(00)00048-6

Luchs, M., \& Swan, K. S. (2011). Perspective: The emergence of product design as a field of marketing inquiry. Journal of Product Innovation Management, 28(3), 327-345. doi: 10.1111/j.15405885.2011.00801.x

Nobeoka, K. (2006). MOT gijutsu keiei nyumon [MOT beginner's book in technology management]. Tokyo, Japan: Nihon Keizai Shimbun Shuppan (in Japanese).

Perks, H., Cooper, R., \& Jones, C. (2005). Characterizing the role of design in new product development: An empirically derived taxonomy. Journal of Product Innovation Management, 22(2), 111127. doi: 10.1111/j.0737-6782.2005.00109.x

Rindova, V. P., \& Petkova, A. P (2007). When is a new thing a good thing? 
Technological change, product form design, and perceptions of value for product innovations. Organization Science, 18(2), 217-232. doi: 10.1287 /orsc. 1060.0233

Takeda, Y. (2000). Product realization senryaku: 3 jigen joho gijutu ga seihinkaihatsu soshiki ni ataeru eikyo [Product realization strategy: How 3D information technology affects product development organization]. Tokyo, Japan: Hakuto shobo (in Japanese).

Thomke, S., \& Fujimoto, T. (2000). The effect of "Front-Loading" problemsolving on product development performance. Journal of Product Innovation Management, 17(2), 128-142. doi: 10.1016/S07376782(99)00031-4

Verganti, R. (2008). Design, meanings, and radical innovation: A metamodel and a research agenda. Journal of Product Innovation Management, 25(5), 436-456. doi: 10.1111/j.15405885.2008.00313.x

Yoshioka, T. (2018). Kakushinteki na seihin ni hukumareru designer hatu no gijutu innovation [Originated technology innovations in innovative products: Roles of industrial designers in innovation]. Maketingu Jyanaru [Marketing Journal]. 38(1), 21-37 (in Japanese). doi: 10.7222/marketing.2018.026

Zhang, D., Hu, P., \& Kotabe, M. (2011). Marketing-industrial design integration in new product development: The case of China. Journal of Product Innovation Management, 28(3), 360-373. doi: 10.1111/j.15405885.2011.00803.x 